\title{
Glacier-specific elevation changes in parts of western Alaska
}

\author{
R. LE BRIS, F. PAUL \\ Department of Geography, University of Zürich, Zürich, Switzerland \\ Correspondence: R. Le Bris <rlebris@geo.uzh.ch>
}

\begin{abstract}
The meltwater from glaciers in Alaska contributes strongly to global sea-level rise, but accurate determination is challenging as only two comparatively small glaciers have long-term measurements of annual mass balance (Gulkana and Wolverine). Simple upscaling of their values to the entire region is error-prone as their representativeness is unknown and might be biased. Alternatively, differencing digital elevation models (DEMs) from two epochs provides overall volume changes for a longer period of time that can be converted to mass changes using appropriate density assumptions. Here we combine outlines from two glacier inventories to determine glacier-specific elevation changes over a $\mathbf{5 0}$ year period for $\mathbf{3 1 8 0}$ glaciers in western Alaska using DEM differencing. This allows us to determine the representativeness of the land-terminating Gulkana and Wolverine Glaciers for the entire region and to exclude calving glaciers (marine and lacustrine) from the sample. Mean changes for all land-terminating, lake-terminating and tidewater glaciers are $-0.23 \pm 0.44,-0.63 \pm 0.40$ and $-0.64 \pm 0.66 \mathrm{~m} \mathrm{a}^{-1}$, respectively, and -0.7 and $-0.6 \mathrm{ma}^{-1}$ for the two mass-balance or benchmark glaciers. Thus fortuitously their changes better represent calving glaciers and the overall mean $\left(-0.63 \pm 1.14 \mathrm{~m} \mathrm{a}^{-1}\right)$ than the change of land-terminating glaciers, i.e. they are not representative for their own type. Different methods of considering potential DEM artefacts provide variable mean changes but the same general result.
\end{abstract}

KEYWORDS: glacier delineation, glacier fluctuations, glacier mass balance, mountain glaciers, remote sensing

\section{INTRODUCTION}

Meltwater from glaciers in Alaska has made a substantial contribution to sea-level rise in the past decades (Arendt and others, 2006; VanLooy and others, 2006; Berthier and others, 2010) and will likely continue to do so in the future (Radić and Hock, 2011; Marzeion and others, 2012; Gardner and others, 2013), assuming further increases in temperature. Gardner and others (2013) determined the sealevel rise contribution of all glaciers globally for 2003-09 using a combination of satellite-based methods (gravimetry and elevation changes) and field-based measurements of glacier mass balance. For the purpose of that study, the sparsely available field data (Zemp and others, 2009) were extrapolated to entire mountain ranges using an inverse distance-weighted (IDW) scheme adopted from Cogley (2009). The high uncertainty of this method is well known, as mass budgets of individual glaciers in the same mountain range can vary strongly (Kuhn and others, 1985; Huss, 2012). However, the measured glaciers were found to have more negative mass budgets than the regional averages obtained by satellite methods, thus introducing a bias towards an overestimation of their sea-level rise contribution (Gardner and others, 2013). Determining the representativeness of the measured mass-balance glaciers for the mass changes of an entire region is thus still a key issue for globalscale extrapolations (Kaser and others, 2006). On the other hand, in regions such as the European Alps, with a wealth of calibration data and repeat digital elevation models (DEMs), such an assessment is readily feasible (Huss, 2012).

In Alaska, only two glaciers (Gulkana and Wolverine) have long-term records of direct mass-balance measurements (Van Beusekom and others, 2010), and DEMs covering large regions are only available for two points in time. These DEMs were used by Berthier and others (2010) to calculate overall mass budgets and sea-level-rise contributions for all glaciers in Alaska over a 50 year time period. That study revealed a high spatial variability of elevation changes and a pronounced thinning of the often low-lying tongues of large valley glaciers. With the recently published glacier inventory for western Alaska (Le Bris and others, 2011), drainage divides of individual glaciers can be digitally intersected with the elevation change raster data and glacierspecific values can be calculated. This also allows exclusion of specific glaciers from the averaging process (e.g. when more than $20 \%$ of the area is covered by data voids in the DEMs) and separating the changes for different types of glaciers (e.g. land-terminating vs tidewater).

By comparing the volume changes derived for the two benchmark glaciers to the overall mean of a selected sample (e.g. all land-terminating glaciers derived by differences of DEMs), a factor can be obtained that allows upscaling of their changes measured for the entire region (Paul and Haeberli, 2008). Of course, such factors only hold for the investigated period and for multi-year (e.g. pentadal) averages of volume changes (Cogley, 2009). But the method is independent of measured mass budgets, thus avoiding problems with an unknown snow/firn/ice density (Huss, 2013) and the challenges of comparing geodetic volume changes to cumulative glacier-wide extrapolations of field measurements of point mass balances (Fischer, 2011; Zemp and others, 2013). The method should also provide more accurate results for an entire region than IDW interpolation. A direct comparison of the geodetic with the glaciologically derived cumulative mass budget for Gulkana Glacier is presented by Cox and March (2004).

In this study we calculate mean elevation changes (i.e. normalized with the area) for a sample of 3180 glaciers in western Alaska to determine the representativeness of the 


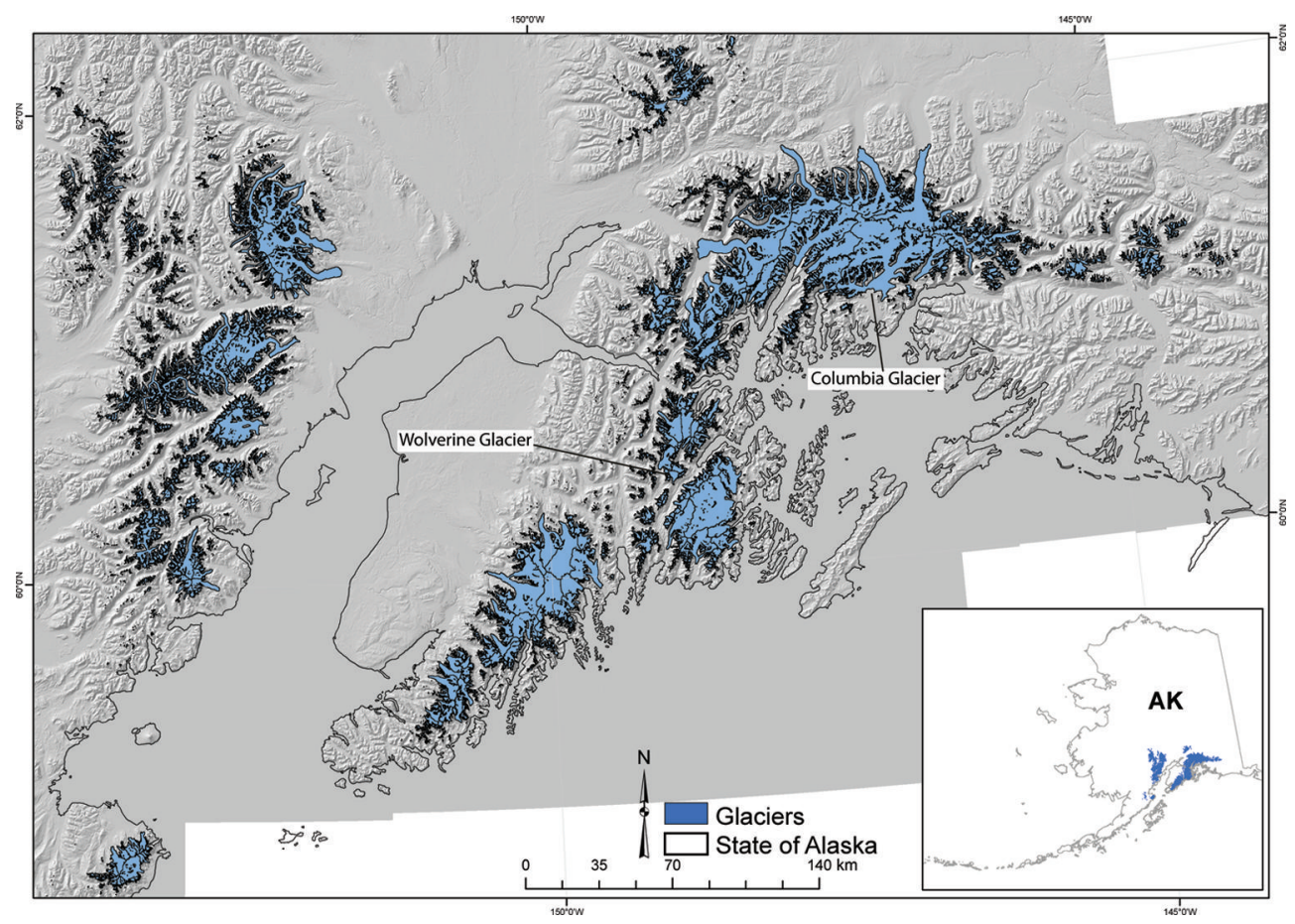

Fig. 1. Location map showing the glaciers (blue) with a hillshade of the NED DEM in the background. Inset shows the study region in Alaska.

two glaciers with long-term mass-balance measurements (Gulkana and Wolverine) for the entire region. Special emphasis is given to the different possibilities of calculating mean values for the entire region (arithmetic or areaweighted) and the treatment of DEM artefacts when deriving glacier-specific mean values.

\section{STUDY REGION, DATA SOURCES AND PROCESSING}

\section{Study region}

The study region is located in the western Alaska Range, including the Tordrillo, Chigmit, Katmai and Chugach Mountains as well as the Kenai Peninsula (Fig. 1). All types of glaciers are present in this region, from cirques, mountain and valley glaciers to ice-clad volcanoes and ice caps. The glacier inventory of western Alaska compiled by Le Bris and others (2011) includes more than 8800 glaciers $>0.02 \mathrm{~km}^{2}$ covering a total area of $16250 \mathrm{~km}^{2}$, which is about $19 \%$ of the glacierized area of Alaska according to Pfeffer and others (2014). Only $0.4 \%$ of the glaciers are $>100 \mathrm{~km}^{2}$ but they account for $47 \%$ of the total area. Only a few glaciers (36) in the study region are calving in lakes (lacustrine) or the ocean (tidewater), but they are comparatively large (e.g. Columbia Glacier, with an area of $945 \mathrm{~km}^{2}$ ). Glaciers stretch from sea level up to $4000 \mathrm{ma}$ a.s.l. and the observed trend of mean elevations implies a significant decrease of precipitation from the coast towards the interior of Alaska (Le Bris and others, 2011).

\section{Datasets and pre-processing}

The glacier outlines used here are a subset of the Digital Line-Graph (DLG) dataset for Alaska compiled by the US Geological Survey (USGS) by either manual or automated digitizing based on large-scale $7.5 \mathrm{~min}$ topographic quadrangle maps ( $1: 25000$ and $1: 63360$ scales for Alaska). For quality control of the DLG outlines we compared them with the Digital Raster Graph (DRG) dataset, which is a highresolution scan of published paper maps that have a date (http://topomaps.usgs.gov/drg). This overlay revealed a systematic planimetric shift between the DLG and the DRG, which is explained on the aforementioned DRG website. The observed outline mismatches (especially in the ablation region of glaciers) were adjusted manually for a subset of the DLG glacier outlines (350 glaciers) according to the DRG maps (Fig. 2) for an evaluation of the impact of non-adjusted extents on glacier mass balance (e.g. Paul, 2010; Huss and others, 2012).

The USGS National Elevation Dataset (NED) is a DEM derived from contours as given on topographic maps from the 1950s (Gesch, 2007) and is used as the base for calculating elevation changes. For Alaska, the NED DEM is available at 2 arcsec postings $(\sim 60 \mathrm{~m})$. The absolute vertical accuracy of the quadrangle-based USGS $7.5 \mathrm{~min}$ DEMs is reported to be $7 \mathrm{~m}$, but due to poor contrast in the accumulation areas accuracy can be much lower (e.g. Aðalgeirsdóttir and others (1998) and Arendt and others (2002) assumed a $45 \mathrm{~m}$ uncertainty in this region). The product was downloaded through the USGS Seamless Server (http://seamless.usgs.gov).

The elevation changes from 1950 to $2006(\Delta h / \Delta t$ raster maps) used here to determine glacier-specific values were derived by Berthier and others (2010) and are based on the subtraction of two DEMs. The older DEM is the USGS NED described above and the more recent DEM was derived from the high-resolution stereoscopic (HRS) sensor on board SPOT 5 (Satellite Pour l'Observation de la Terre) (Bouillon and others, 2006) and created within the framework of the International Polar Year (IPY) project SPIRIT (Spot 5 stereoscopic survey of Polar Ice: Reference Images and Topographies, Université de Toulouse) described by Korona and others (2009). This DEM has a $40 \mathrm{~m}$ cell size, a horizontal confidence region of $30 \mathrm{~m}$, and a vertical 
a

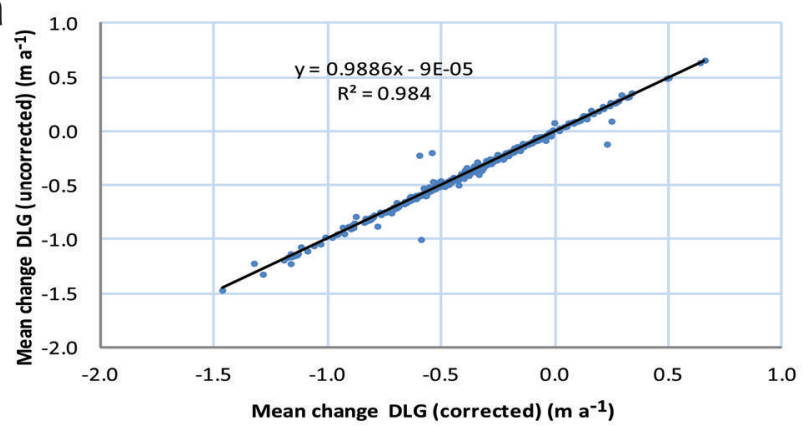

$\mathrm{b}$

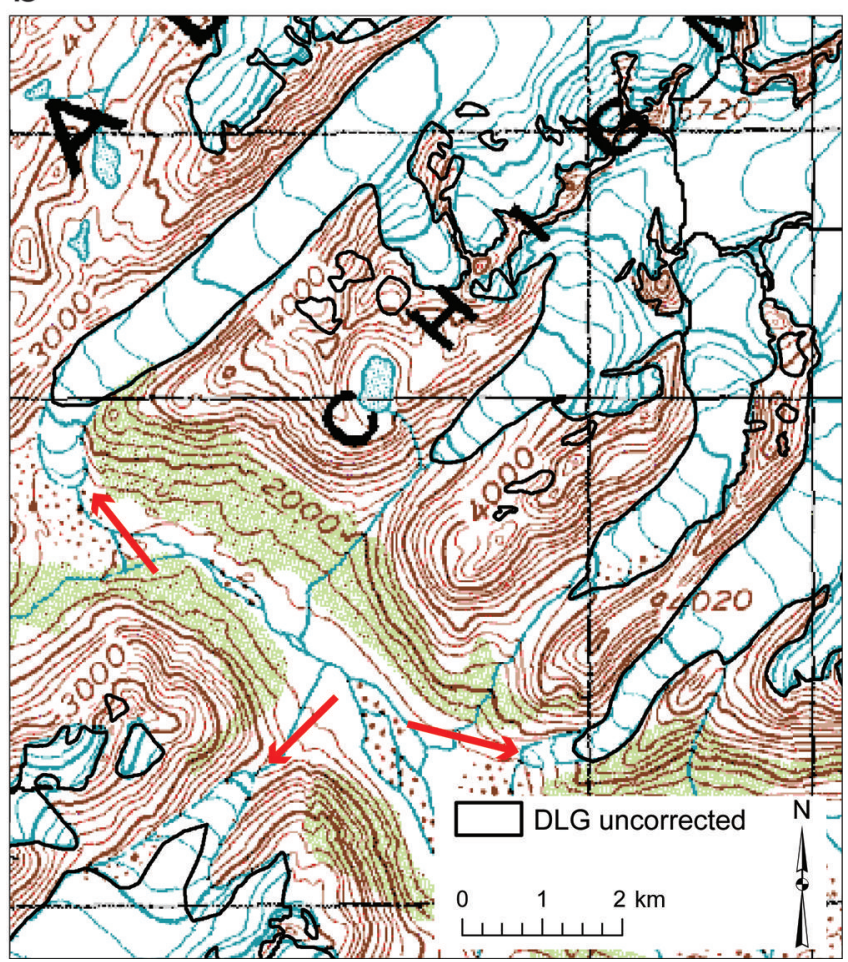

Fig. 2. (a) Elevation change for uncorrected DLG vs corrected DLG glacier outlines. (b) Red arrows show the glacier extents visible on the topographic map (DRG).

confidence region between -5.5 and $+3.5 \mathrm{~m}$ (compared with the Ice, Cloud and land Elevation Satellite (ICESat)). Nonetheless, an elevation uncertainty of $\pm 10 \mathrm{~m}$ is assumed over the entire study area.

To determine elevation changes for the two benchmark glaciers, which had too many data voids in the SPIRIT DEM, we also used the Advanced Spaceborne Thermal Emission and Reflection Radiometer (ASTER) global DEM (GDEM2) compiled from all available stereo-pair images in the ASTER archive acquired between 2000 and 2011. The GDEM2 has a spatial resolution of $30 \mathrm{~m}$ and a vertical accuracy of about 7-14 m (standard deviation) (ASTER Validation Team, 2009; Fujisada and others, 2012).

Individual glacier extents were derived by digital intersection with drainage divides derived from hydrological computations (watershed analysis) using the NED DEM and GIS tools following the approach of Bolch and others (2010). Hillshade images were created for all DEMs to check quality and artefacts.

\section{METHODS}

As a first step of the statistical analysis, glaciers $<0.05 \mathrm{~km}^{2}$ or with $>20 \%$ of their area covered by data voids are excluded. In a second step three types of glaciers are distinguished (i.e. marked in the attribute table): land-terminating, laketerminating and tidewater glaciers. Outside of data voids, DEM artefacts can occur in areas of low contrast (e.g. covered by snow and shaded slopes) that might result in artificial positive elevation changes (i.e. mass gain). To determine the influence of these regions on the mean values, we calculated mean elevation changes for each glacier by three different methods: (a) for the ablation areas only (regions below the mean elevation as a rough proxy for the long-term equilibrium-line altitude (ELA)); (b) by setting all positive elevation changes to 'no data'; and (c) by setting them to 0 (Table 1). The glacier-specific mean elevation changes for the three samples (a), (b) and (c) were then averaged for the entire region in two statistically different ways: (1) one mean value for the entire study region to determine the overall changes (area-weighted); and (2) the arithmetic mean of all individual mean elevation changes.

Owing to the different cell sizes of the DEMs subtracted (30, 40 and $60 \mathrm{~m}$ ), resampling effects and elevationdependent biases might occur in the difference grid (Paul and Haeberli, 2008); they can be corrected by considering the maximum terrain curvature (Gardelle and others, 2012). However, we did not find any systematic elevation changes for terrain outside of glaciers (Fig. 3) and thus have not corrected for them. This lack of systematic change is likely due to the very similar level of detail in all three DEMs as seen in a visual comparison of hillshades.

To assess the usefulness of the GDEM2 for determining elevation changes, we computed mean elevation changes

Table 1. Mean elevation change as a function of glacier type calculated by two methods of averaging: $n=1$ uses one mean value for the entire study region; $\Sigma$ glacier uses the arithmetic mean of individual mean elevation changes. Rows $2-4$ reflect different ways of calculating the influence of potential DEM artefacts. Corr. $f$. is the multiplicative correction factor (required to obtain the mean value of the landterminating glaciers)

\begin{tabular}{|c|c|c|c|c|c|c|c|c|c|c|}
\hline & \multicolumn{2}{|c|}{ Land-terminating } & \multicolumn{2}{|c|}{ Lake-terminating } & \multicolumn{2}{|c|}{ Tidewater } & \multicolumn{2}{|c|}{ Gulkana } & \multicolumn{2}{|c|}{ Wolverine } \\
\hline & $\begin{array}{l}n=1 \\
\mathrm{ma}^{-1}\end{array}$ & $\begin{array}{c}\Sigma \text { glacier } \\
\mathrm{ma}^{-1}\end{array}$ & $\begin{array}{l}n=1 \\
\mathrm{ma}^{-1}\end{array}$ & $\begin{array}{c}\Sigma \text { glacier } \\
\mathrm{ma}^{-1}\end{array}$ & $\begin{array}{l}n=1 \\
\mathrm{ma}^{-1}\end{array}$ & $\begin{array}{c}\Sigma \text { glacier } \\
\mathrm{ma}^{-1}\end{array}$ & $\mathrm{ma}^{-1}$ & Corr. f. & $\mathrm{ma}^{-1}$ & Corr. $\mathrm{f}$. \\
\hline All cells & -0.42 & -0.24 & -0.58 & -0.63 & -1.81 & -0.64 & -0.68 & $1 / 2.87$ & -0.59 & $1 / 2.52$ \\
\hline Ablation zone only (a) & -0.68 & -0.33 & -1.03 & -1.04 & -2.86 & -0.94 & -1.01 & $1 / 3.06$ & -0.76 & $1 / 2.31$ \\
\hline No data $(b)$ & -0.69 & -0.47 & -0.90 & -0.86 & -2.12 & -0.86 & -0.78 & $1 / 1.66$ & -0.68 & $1 / 1.43$ \\
\hline Set to zero (c) & -0.52 & -0.37 & -0.67 & -0.70 & -1.85 & -0.70 & -0.71 & $1 / 1.93$ & -0.62 & $1 / 1.68$ \\
\hline
\end{tabular}




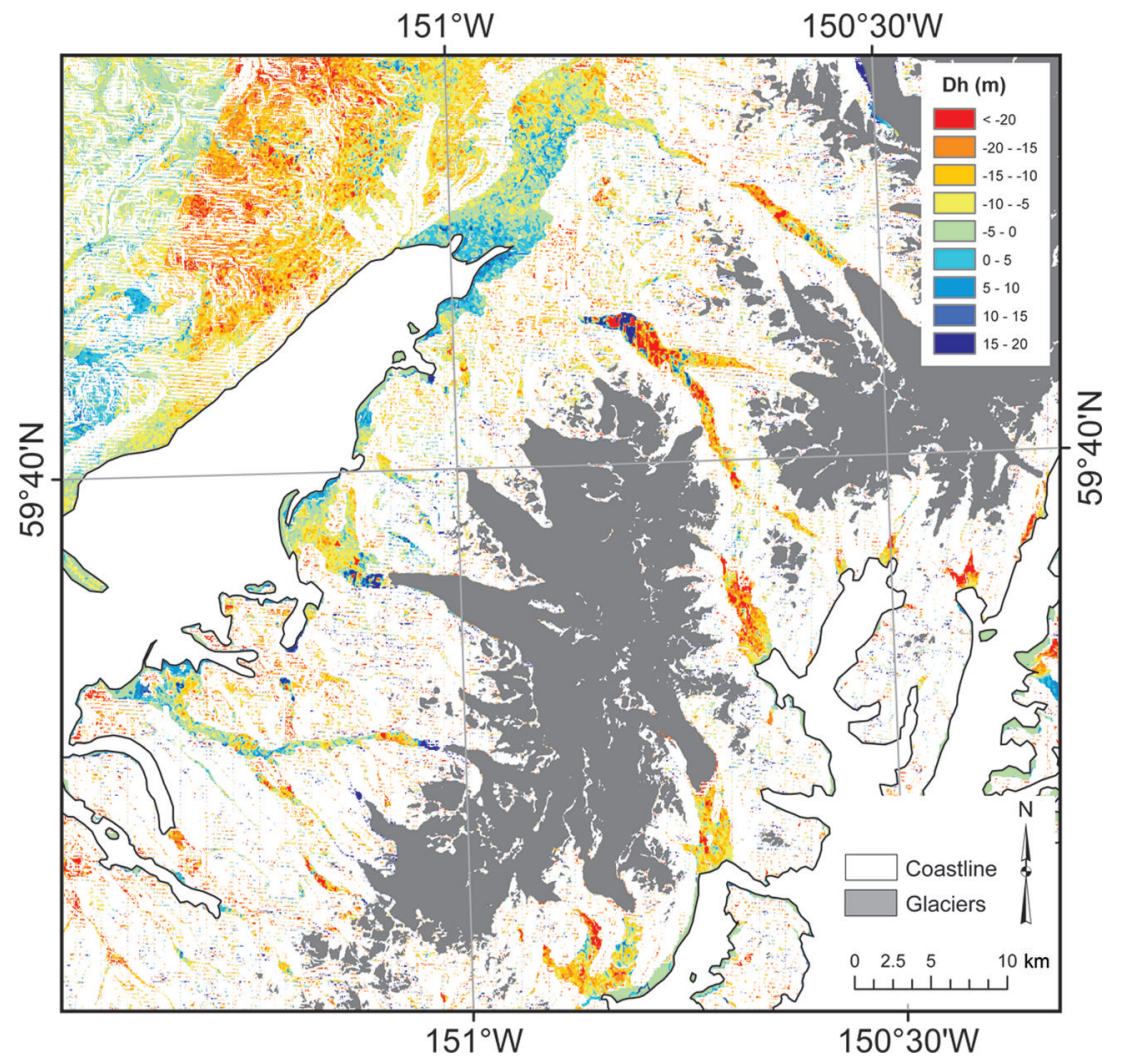

Fig. 3. Elevation differences between NED and GDEM2 for flat terrain off glaciers (with slopes $<5^{\circ}$ ).

between the GDEM2 and the NED DEM (Fig. 3) and compared them with the values derived from the dataset of Berthier and others (2010) using SPOT data. Co-registration between the NED DEM and the GDEM2 was achieved following the method developed by Nuth and Kääb (2011), which uses terrain aspect to quantify the offset values with an iterative approach.

Owing to data voids covering $>20 \%$ of the area in the $\Delta h / \Delta t$ raster maps for the two benchmark glaciers (Gulkana and Wolverine), we had to determine elevation changes specifically for these glaciers by differencing the NED DEM and the GDEM2 (a useful DEM derived from only one ASTER scene was not available). To determine if the multiyear composite GDEM2 is suitable for this purpose, we compared glacier-specific elevation changes derived with the GDEM2 to those derived from the SPOT DEM for other glaciers. Mean elevation changes for each glacier were calculated using zone statistics in the GIS software and divided by the number of years between the two DEMs to obtain rates of elevation change. Topographic maps were acquired over a 7 year period so that using the mean value of the epoch as a reference date results in an uncertainty of \pm 3.5 years, which translates into an elevation uncertainty of $\pm 2.5 \mathrm{~m}$ according to Arendt and others (2006) and Berthier and others (2010).

\section{RESULTS}

\section{Elevation changes}

In total, elevation changes were calculated for $\sim 3180$ glaciers. The mean change (area-weighted) for the entire study region is $-0.67 \pm 0.76 \mathrm{ma}^{-1}$, with a mean value of $-0.42 \pm 0.35 \mathrm{~m} \mathrm{a}^{-1}$ for land-terminating glaciers,
$-0.58 \pm 0.87 \mathrm{~m} \mathrm{a}^{-1}$ for lake-terminating glaciers, and $1.81 \pm 2.24 \mathrm{~m} \mathrm{a}^{-1}$ for tidewater glaciers including Columbia Glacier and $-0.60 \pm 0.90 \mathrm{ma}^{-1}$ excluding it. The extreme loss of Columbia Glacier $\left(-2.8 \mathrm{~m} \mathrm{a}^{-1}\right)$ has a strong impact on the area-weighted mean thinning rate.

Colour-coded glacier-specific mean values of elevation change for three subsections of the study region are shown in Figure 4. The high variability in the changes is evident in Figure 4, even for glaciers originating at the same mountain ridge. A more detailed analysis revealed that mean elevation changes are weakly correlated with glacier size, but not with mean slope, exposition or mean elevation. Several small to medium-sized glaciers experienced a net increase in elevation when the differences were used as calculated. In some cases these increases might be related to artefacts in the DEM that have an increasing impact on the mean value towards smaller glaciers.

Such artefacts are also visible in Figure 5, illustrating the spatial distribution of elevation changes on a gridcell level. Apart from Matanuska Glacier (D), all glaciers experienced moderate to strong elevation loss in their lower parts, largely independent of their geographic location. For Gulkana (B), Wolverine (E) and in a less pronounced way also for Trimble Glacier (F), surface lowering also occurred in the accumulation area. Positive elevation changes $>0.5 \mathrm{~m} \mathrm{a}^{-1}$ are mostly located towards the glacier boundary and at steep slopes. They might thus represent DEM artefacts or result from the different DEM cell sizes compared. Values between 0 and $+0.5 \mathrm{~m} \mathrm{a}^{-1}$ are within the uncertainty range of the DEMs and can be real or not. The gain/loss dipole in the accumulation region of Wolverine Glacier could also be an artefact of local DEM quality (e.g. Koblet and others, 2010).

The impact of the different methods for excluding potential artefacts (positive changes) from calculations of mean 

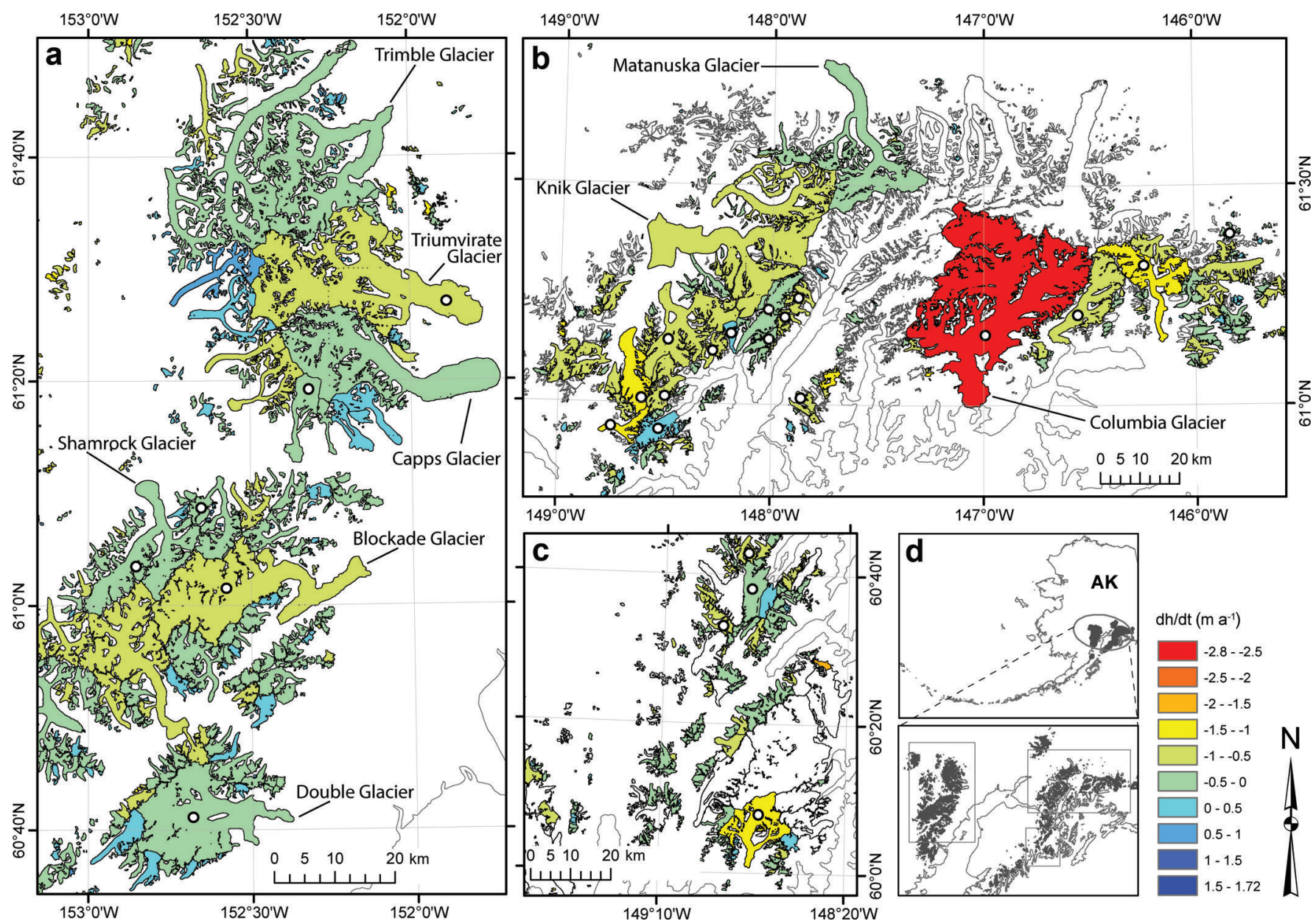

Fig. 4. Examples of mean elevation changes in (a) Tordrillo and Chigmit Mountains, (b) Chugach Mountains and (c) Kenai Peninsula. White dots indicate lake-terminating and tidewater glaciers. White glaciers represent those with $>20 \%$ data voids. (d) Insets show the location of the mountain ranges in Alaska.

values are listed in Table 1 for the three types of glacier and two types of averaging. In general, the mean changes are more negative for the area-weighted calculation (landterminating and tidewater), but for lake-terminating glaciers they are very similar. Regarding the different methods for considering positive changes, mean changes are (as expected) in general more negative when only the ablation area (below the mean elevation) is considered. However, for land-terminating glaciers the replacement of positive values with no data gives even more negative changes, indicating that substantial surface lowering also took place above the mean elevation. For some glaciers (e.g. C and F in Fig. 5) artefacts (or general DEM errors) might also be related to negative changes (red spots in the accumulation region). These have not been considered for correction here as they occur much less frequently, thus having a small impact on the overall mean (i.e. real changes would be slightly less negative); however, when analysing individual glaciers there might be a need to correct for these as well.

Figure 6 illustrates the elevation changes averaged over $50 \mathrm{~m}$ elevation bins for the ten largest land-terminating glaciers and the two benchmark glaciers (Gulkana and Wolverine). For all glaciers the strongest losses occurred at their lowest parts between 250 and $750 \mathrm{~m}$ a.s.l. Between 1000 and $2000 \mathrm{~m}$ a.s.l., changes are similar for the largest glaciers, apart from Gulkana Glacier, which over large parts of its elevation range has much stronger losses than all other glaciers at this elevation. Towards higher elevations several glaciers show thickening (e.g. Capps Glacier with up to $0.5 \mathrm{~m} \mathrm{a}^{-1}$ ), some show little change and some show increasing loss with altitude, as mentioned above. However, some of these changes are likely related to artefacts, implying that the values should not be over-interpreted.

Further investigations on the dependence of elevation changes on other glacier parameters (e.g. size, mean elevation, elevation range, slope and distance from the ocean) did not reveal any significant correlations (Fig. 7), indicating local highly variable climatic regimes and glacier responses that also depend on the variable geometry of each glacier (i.e. its hypsometry).

\section{Correction factors}

Whether one prefers to compare the mean values of Gulkana and Wolverine Glaciers $\left(-0.7\right.$ and $\left.-0.6 \mathrm{~m} \mathrm{a}^{-1}\right)$ with the values from either the arithmetic or the area-weighted averaging of the respective larger sample is a matter of purpose. To determine their representativeness, we compare them with the arithmetic means, revealing that their values are much more negative (factor of 2-3) than for the other land-terminating glaciers $\left(-0.24 \mathrm{~m} \mathrm{a}^{-1}\right)$. In fact, their values are much closer to the other two types of glacier (in particular lake-terminating), and also when considering the three ways of excluding artefacts (Table 1).

In other words, extrapolating the changes for these two glaciers would overestimate the losses of other landterminating glaciers by a factor of 2.5 (for Wolverine) and 


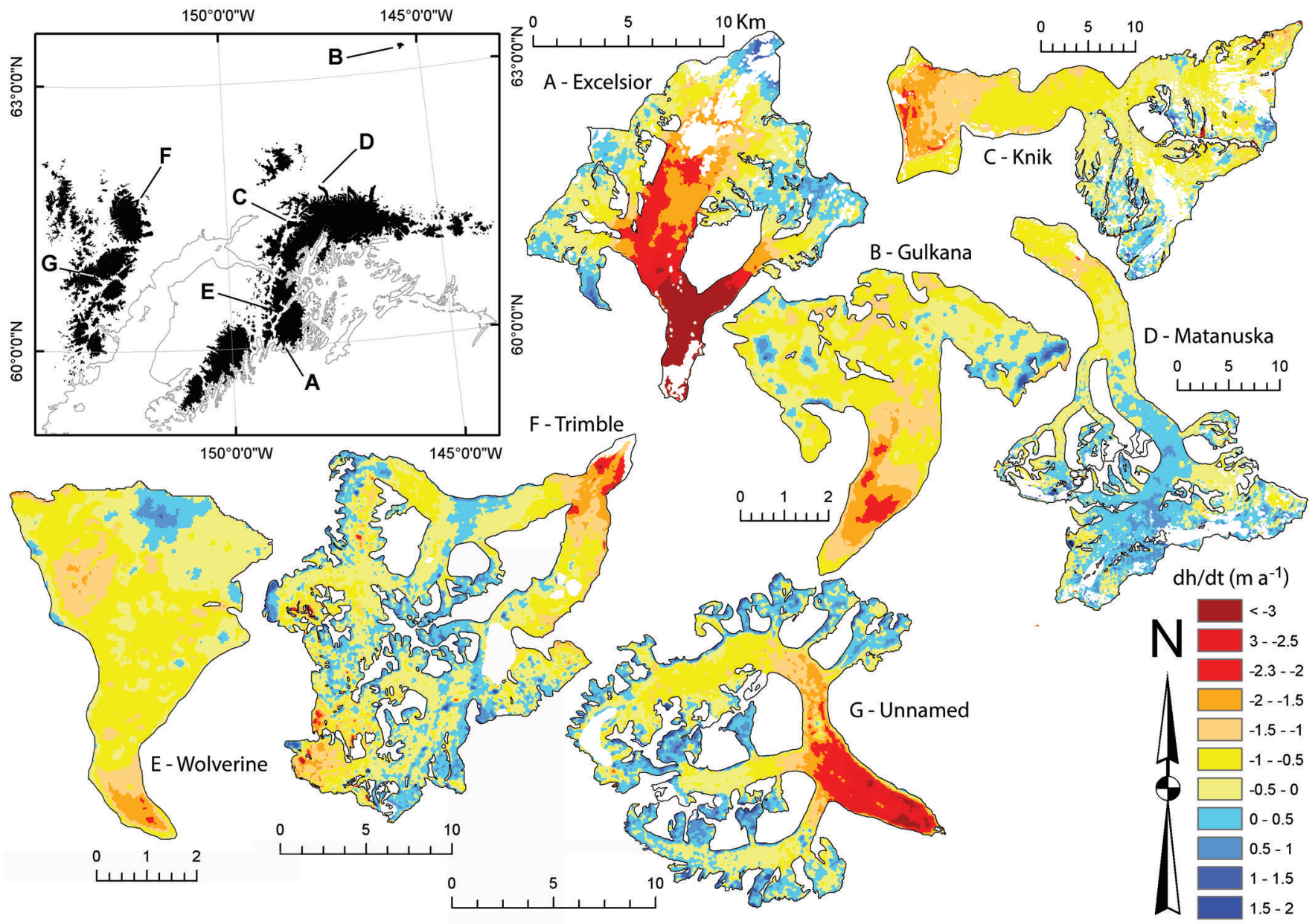

Fig. 5. Elevation changes for seven glaciers. Glacier outlines are from the DLG dataset. White areas indicate no data. Inset shows the location of the seven glaciers. A: Excelsior Glacier; B: Gulkana Glacier; C: Knik Glacier; D: Matanuska Glacier; E: Wolverine Glacier; F: Trimble Glacier; G: unnamed glacier in the Chigmit Mountains.

2.9 (for Gulkana), consistent with the results of Gardner and others (2013) who concluded that measured glaciers introduce a bias when simply extrapolated to their surrounding regions. On the other hand, their mean change is very close to the mean of the entire region (including the calving glaciers) and they can thus be considered representative for the entire region investigated here. When the exceptionally strong elevation loss of Columbia Glacier is excluded, the agreement is less good, and uncorrected extrapolation would yield mass budgets $\sim 30 \%$ too negative. However, when considering the standard deviations, the mean elevation change rates for the three glacier types are not significantly different and should thus be interpreted prudently. It also should be emphasized that the above factors are only valid for the time period covered by the two DEMs and might be different for other periods.

\section{Accuracy of the GDEM2}

Data voids were too large in the SPIRIT DEM over Gulkana and Wolverine Glaciers, so we had to use the GDEM2 to calculate elevation changes with the NED DEM. As the GDEM2 is a merged multitemporal product, it is necessary to determine whether it can be used as an alternative to the product derived from SPOT. For this purpose we first determined the elevation differences between the GDEM2 and the SRTM DEM for weakly inclined (slopes $<5^{\circ}$ ) and stable terrain off-glaciers for a region south of Wolverine
Glacier (Fig. 3). The mean difference is $-6.13 \pm 12.2 \mathrm{~m}$ when masking all glaciers and the ocean. At first glance this is a high value, but as shown clearly in Figure 3 it is mostly due to artefacts of the GDEM2. There are issues with regions of low or confusing contrast (e.g. from gravel plains that are related to the three well-confined regions in the middle and upper right of Fig. 3), as well as along boundaries of the merged ASTER tracks (Fig. 3, upper left). Overall, this comparison

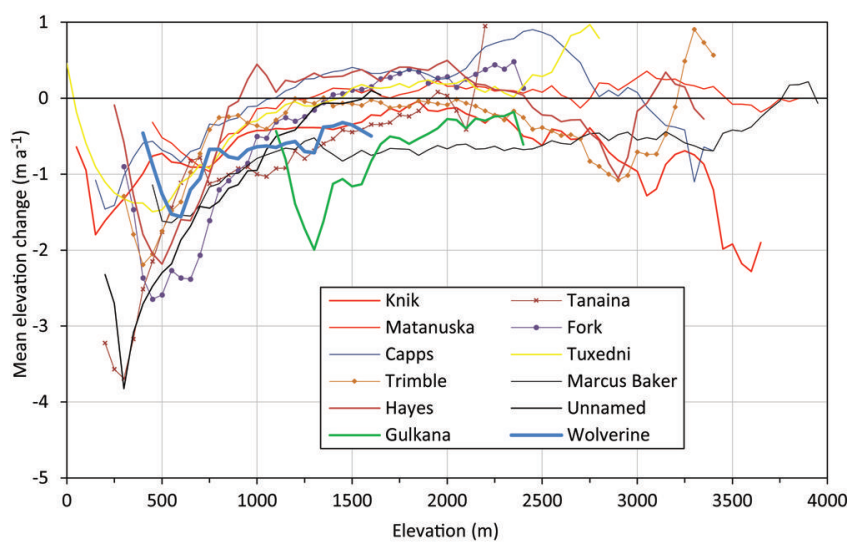

Fig. 6. Mean elevation changes in $50 \mathrm{~m}$ elevation bins for the ten largest glaciers. Gulkana $\left(17.9 \mathrm{~km}^{2}\right)$ and Wolverine $\left(17.17 \mathrm{~km}^{2}\right)$ benchmark glaciers are also included. 

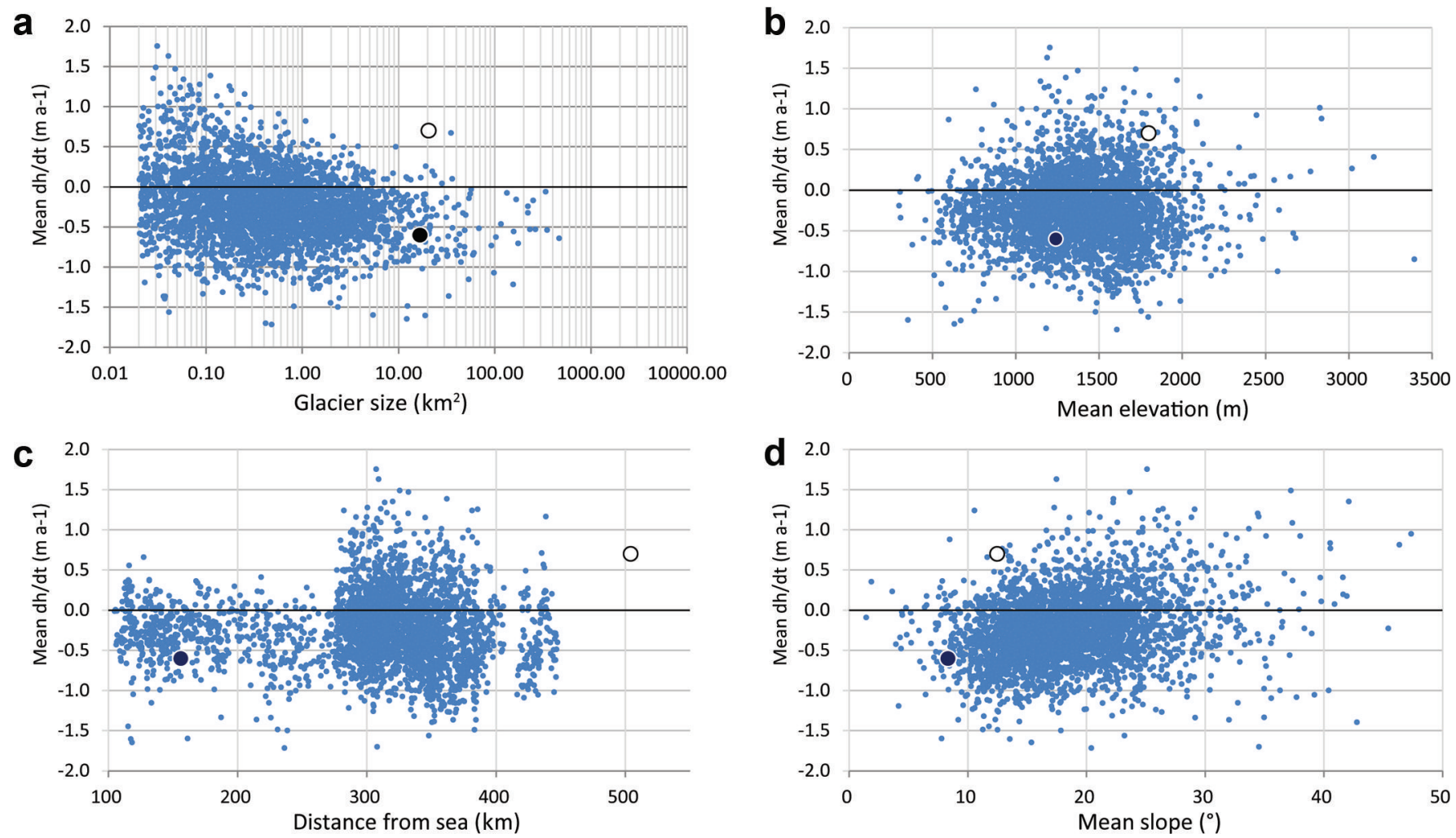

Fig. 7. Elevation change vs other glacier parameters: (a) glacier size, (b) mean elevation, (c) distance from the ocean and (d) elevation range. Black and white dots represent Wolverine and Gulkana Glaciers, respectively.

revealed the well-known problems of the GDEM2, but was not conclusive about its accuracy. By visually excluding the artefact regions, most elevation differences are in the $\pm 5 \mathrm{~m}$ range (green and cyan), pointing to a mean difference much closer to zero and thus acceptable for the purpose of this study. However, as this result is somewhat unsatisfactory, we also compared mean elevation changes derived with both DEM pairs (NED/GDEM2 and NED/SPOT) for a sample of 2940 glaciers (Fig. 8). In general, there are no size-dependent trends of the differences and the scatter increases towards smaller glaciers. Table 2 lists size-class-specific mean values and standard deviations. For the $10-20 \mathrm{~km}^{2}$ size class (encompassing 72 glaciers) of Gulkana $\left(17.17 \mathrm{~km}^{2}\right)$ and Wolverine $\left(17.8 \mathrm{~km}^{2}\right)$ Glaciers, the standard deviation is only $0.12 \mathrm{~m} \mathrm{a}^{-1}$ and thus within acceptable limits of such measurements (Zemp and others, 2013). The NED/ GDEM2-derived values for the two glaciers were finally

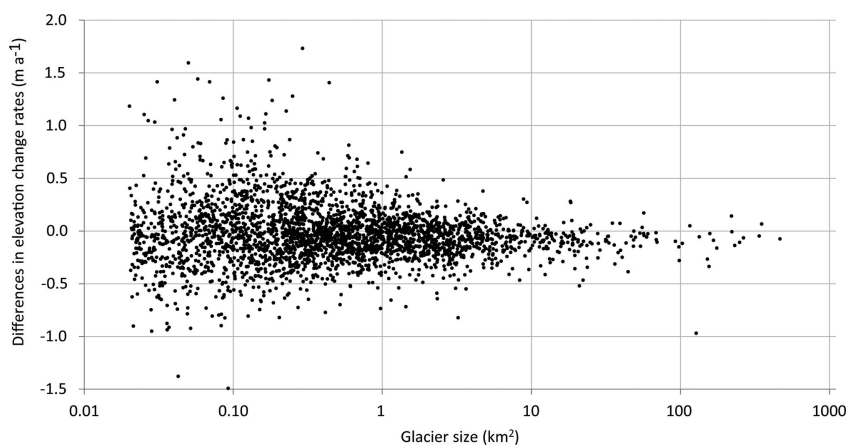

Fig. 8. Comparison of the mean elevation changes derived with both DEM pairs (NED/GDEM2 and NED/SPOT) for a sample of 2940 glaciers. bias-corrected with the mean difference to the NED/SPOTderived values of this size class $\left(0.09 \mathrm{~m} \mathrm{a}^{-1}\right)$.

\section{DISCUSSION}

\section{Elevation changes}

The general tendency of glacier volume loss found here is in line with earlier studies in this region (Arendt and others, 2002; Berthier and others, 2010), but is now also available as a mean value for individual glaciers. This allowed us to exclude lake-terminating and tidewater glaciers from the sample and to determine how the mean elevation changes of the two benchmark glaciers compare to the means of all

Table 2. Differences in elevation changes over glaciers (mean and standard deviation) derived from two combinations of DEMs (NED/ SPOT and NED/GDEM2) for 2940 glaciers of different sizes (see Fig. 8 for individual differences) sorted for size class. Note that, for the $100-500 \mathrm{~km}^{2}$ size class, one outlier (Excelsior Glacier) was removed

\begin{tabular}{lcc}
\hline $\begin{array}{l}\text { Size class } \\
\mathrm{km}^{2}\end{array}$ & $\begin{array}{c}\text { Mean } \\
\mathrm{m} \mathrm{a}^{-1}\end{array}$ & $\begin{array}{c}\text { Std dev. } \\
\mathrm{m} \mathrm{a}^{-1}\end{array}$ \\
\hline $0.1-0.5$ & 0.01 & 0.31 \\
$0.5-1.0$ & -0.03 & 0.23 \\
$1.0-5.0$ & -0.06 & 0.17 \\
$5.0-10$ & -0.09 & 0.13 \\
$10-20$ & -0.09 & 0.12 \\
$20-50$ & -0.13 & 0.14 \\
$50-100$ & -0.06 & 0.10 \\
$100-500$ & -0.13 & 0.12 \\
\hline
\end{tabular}


other land-terminating glaciers. The two benchmark glaciers had about two to three times more negative changes, thus confirming the findings of Fountain and others (2009) and Gardner and others (2013) that the glaciers selected for mass-balance measurements might have a negative bias. Compared with the other glaciers in the region, the benchmark glaciers might be smaller or larger, located at a different elevation, too flat and/or less shaded. However, this changes when calving glaciers are also considered, as they have similar loss rates to the two benchmark glaciers (about $-0.6 \mathrm{~m} \mathrm{a}^{-1}$ ). Hence, for determination of the sea-level contribution of the entire region their specific mass budgets can indeed be considered representative and thus used for an upscaling over the region and time period investigated herein (Kaser and others, 2006).

This is similar for the Alps, where some of the measured glaciers also had much more negative mass balances over a 15 year period than the other glaciers in their size class (Paul and Haeberli, 2008; Huss, 2012). However, they also represent quite well the mean over the entire region as the (unmeasured) largest glaciers contribute much more strongly to the total volume change, as has been revealed from DEM differencing. Thus, despite their different characteristics, the measured glaciers seem to be suitable for upscaling of their mass budgets to the entire region, at least over the time period analysed here.

The extreme loss $\left(-2.8 \mathrm{ma}^{-1}\right)$ and large size (nearly $1000 \mathrm{~km}^{2}$ ) of Columbia Glacier are both exceptional characteristics. The changes of this glacier have a strong impact on the overall mean when an area-weighted mean value is determined. However, as the elevation change of tidewater glaciers is also influenced by glacier dynamics rather than climate change (Pfeffer and others, 2008), they should be excluded from the sample when climate change impacts are analysed. In this case the surface elevation loss is also different from the sea-level equivalent volume loss, as the loss of ice below sea level is not measured (McNabb and others, 2012). The ice volume lost below sea level will be replaced by ocean water with a $10 \%$ higher density, thus lowering sea level (Haeberli and Linsbauer, 2013).

\section{Uncertainties}

Several uncertainties influence the quality of our results, including: (1) the artefacts in the DEMs; (2) the partially updated glacier extents in the DLG; (3) the use of the GDEM2 instead of the SPOT DEM for the two benchmark glaciers; and (4) uncorrected biases (e.g. due to different DEM resolutions). As we have already discussed points (3) and (4), some comments on points (1) and (2) have to be made.

To be reliable, the overall elevation changes should be larger than the accuracy of the two DEMs. For most glaciers this is true in the ablation area, but less so in the accumulation area. Elevation increases can be real in a very maritime climate, such as coastal Alaska or Norway (Andreassen and others, 2005), but they can also be artefacts, in particular when the increase occurs on steep slopes or over shaded or snow-covered terrain with reduced optical contrast (see Fig. 5), the regions typical of poor performance of optical DEMs (e.g. Frey and Paul, 2012; Gardelle and others, 2013). When it is not possible to identify these artefacts, setting positive elevation changes to no data may be the best way of excluding potentially wrong values from the analysis. Setting these positive values simply to zero might already introduce a bias, but, as the mean values show (Table 1), the differences between the two methods of calculation are small.

To determine the influence of (2), we corrected the outlines of 350 glaciers from the DLG according to the DRG and compared the mean elevation changes for the corrected and uncorrected extents (Fig. 2). This comparison revealed larger (non-systematic) deviations for only five glaciers, so that in the mean over the entire sample the influence of the missing correction on the calculated change rates is small. After the five outliers are removed, the correlation coefficient and standard deviation are 0.99 and $0.35 \mathrm{~m} \mathrm{a}^{-1}$, respectively.

When the overall changes are dominated by a few glaciers, arithmetic averaging does indeed give a different mean value than that resulting from an area-weighted calculation. While the latter should be used when calculating the sea-level contribution (Berthier and others, 2010), the arithmetic mean fits better to the mean values of the direct measurements, as they are also arithmetically averaged.

\section{CONCLUSIONS}

We have calculated mean elevation changes for 3180 glaciers in western Alaska from two DEMs acquired $\sim 50$ years apart to determine the representativeness of Gulkana and Wolverine Glaciers for the mean elevation changes of the entire region. We excluded glaciers with extents $>20 \%$ covered by data voids and distinguished three types of glacier, four methods to handle possible artefacts, and two methods for statistical averaging of the overall changes. For the two benchmark glaciers we had to use another DEM (GDEM2 instead of SPOT), so we also determined the impact on the derived change values of using this alternative DEM.

Rates of elevation change are $-0.63 \pm 0.40 \mathrm{~m} \mathrm{a}^{-1}$ for both lake-terminating and tidewater glaciers and $-0.24 \pm$ $0.44 \mathrm{~m} \mathrm{a}^{-1}$ for land-terminating glaciers. Thus, simple extrapolation of the mean elevation changes for Gulkana and Wolverine Glaciers $\left(-0.7\right.$ and $-0.6 \mathrm{~m} \mathrm{a}^{-1}$ ) would strongly overestimate the contribution from all other land-terminating glaciers, and correction factors of $1 / 2.5$ and $1 / 2.9$, respectively, would be required. However, these two glaciers represent quite well the mean value for other glacier types and the overall changes, at least when Columbia Glacier is part of the sample. Otherwise a 30\% overestimation of mass loss would result. The simple extrapolation of the measurements from the two benchmark glaciers to the entire region, as applied in previous studies, might thus have provided good results, albeit fortuitously. The spatial variability of mean elevation changes across the study region is high, but not related to specific topographic factors. The elevation values derived with the NED/GDEM2 are in good agreement with results from the NED/SPOT, at least for the larger glaciers.

\section{ACKNOWLEDGEMENTS}

This study was funded by the European Space Agency project Glaciers_cci (4000101778/10/I-AM) and the ice2sea programme from the European Union 7th Framework Programme, grant No. 226375. This is ice2sea contribution No. 096. We thank E. Berthier for providing the mean elevation change raster maps of the study region. Constructive reviews by J.G. Cogley and two anonymous reviewers of an earlier version of this paper are gratefully acknowledged. We also thank C. Larsen, an anonymous reviewer and the editor for helpful comments on the manuscript. 


\section{REFERENCES}

Aðalgeirsdóttir G, Echelmeyer KA and Harrison WD (1998) Elevation and volume changes on the Harding Icefield, Alaska. J. Glaciol., 44(148), 570-582

Andreassen LM, Elvehøy $\mathrm{H}$, Kjøllmoen B, Engeset RV and Haakensen N (2005) Glacier mass-balance and length variation in Norway. Ann. Glaciol., 42, 317-325 (doi: 10.3189/ 172756405781812826)

Arendt AA, Echelmeyer KA, Harrison WD, Lingle CS and Valentine VB (2002) Rapid wastage of Alaska glaciers and their contribution to rising sea level. Science, 297(5580), 382-386 (doi: 10.1126/science.1072497)

Arendt A and 7 others (2006) Updated estimates of glacier volume changes in the western Chugach Mountains, Alaska, and a comparison of regional extrapolation methods. J. Geophys. Res., 111, F03019 (doi: 10.1029/2005JF000436)

ASTER Validation Team (2009) ASTER Global DEM validation summary report. ASTER GDEM Validation Team http://www. ersdac

Berthier E, Schiefer E, Clarke GKC, Menounos B and Rémy F (2010) Contribution of Alaskan glaciers to sea-level rise derived from satellite imagery. Nature Geosci., 3(2), 92-95 (doi: 10.1038/ ngeo737)

Bolch T, Menounos B and Wheate R (2010) Landsat-based inventory of glaciers in western Canada, 1985-2005. Remote Sens. Environ., 114(1), 127-137 (doi: 10.1016/j.rse.2009.08.015)

Bouillon A, Bernard M, Gigord P, Orsoni A, Rudowski V and Baudoin A (2006) SPOT 5 HRS geometric performances: using block adjustment as a key issue to improve quality of DEM generation. ISPRS J. Photogramm. Rem. Sens., 60(3), 134-146 (doi: 10.1016/j.isprsjprs.2006.03.002)

Cogley JG (2009) Geodetic and direct mass-balance measurements: comparison and joint analysis. Ann. Glaciol., 50(50), 96-100 (doi: 10.3189/172756409787769744)

Cox LH and March RS (2004) Comparison of geodetic and glaciological mass-balance techniques, Gulkana Glacier, Alaska, USA. J. Glaciol., 50(170), 363-370 (doi: 10.3189/ 172756504781829855)

Fischer A (2011) Comparison of direct and geodetic mass balances on a multi-annual time scale. Cryosphere, 5(1), 107-124 (doi: 10.5194/tc-5-107-2011)

Fountain AG, Hoffman MJ, Granshaw F and Riedel J (2009) The 'benchmark glacier' concept - does it work? Lessons from the North Cascade Range, USA. Ann. Glaciol., 50(50), 163-168 (doi: 10.3189/172756409787769690)

Frey $\mathrm{H}$ and Paul F (2012): On the suitability of the SRTM DEM and ASTER GDEM for the compilation of topographic parameters in glacier inventories. Int. J. Appl. Earth Obs. Geoinform., 18, 480-490 (doi: 10.1016/j.jag.2011.09.020)

Fujisada H, Urai M and Iwasaki A (2012) Technical methodology for ASTER global DEM. IEEE Trans. Geosci. Remote Sens., 50(10), 3725-3736 (doi: 10.1109/TGRS.2012.2187300)

Gardelle J, Berthier E and Arnaud Y (2012) Impact of resolution and radar penetration on glacier elevation changes computed from DEM differencing. J. Glaciol., 58(208), 419-422 (doi: 10.3189/ 2012JoG11J175)

Gardelle J, Berthier E, Arnaud Y and Kääb A (2013) Region-wide glacier mass balances over the Pamir-Karakoram-Himalaya during 1999-2011. Cryosphere, 7, 1263-1286 (doi: 10.5194/tc7-1263-2013)

Gardner AS and 15 others (2013) A reconciled estimate of glacier contributions to sea level rise: 2003 to 2009. Science, 340(6134), 852-857 (doi: 10.1126/science.1234532)

Gesch D (2007) The national elevation dataset. In Maure D ed. Digital elevation model technologies and applications: the DEM users manual, 2nd edn. American Society for Photogrammetry and Remote Sensing, Bethesda, MD, 99-118

Haeberli W and Linsbauer A (2013) Global glacier volumes and sea level - small but systematic effects of ice below the surface of the ocean and of new local lakes on land. Cryosphere, 7(3), 817-821 (doi: 10.5194/tc-7-817-2013)

Huss M (2012) Extrapolating glacier mass balance to the mountain range scale: the European Alps 1900-2100. Cryosphere, 6, 713-727 (doi: 10.5194/tc-6-713-2012)

Huss M (2013) Density assumptions for converting geodetic glacier volume change to mass change. Cryosphere, 7(3), 877-887 (doi: 10.5194/tc-7-877-2013)

Huss M, Hock R, Bauder A and Funk M (2012) Conventional versus reference-surface mass balance. J. Glaciol., 58(208), 278-286 (doi: 10.3189/2012JoG11J216)

Kaser G, Cogley JG, Dyurgerov MB, Meier MF and Ohmura A (2006) Mass balance of glaciers and ice caps: consensus estimates for 1961-2004. Geophys. Res. Lett., 33, L19501 (doi: 10.1029/2006GL027511)

Koblet T and 6 others (2010) Reanalysis of multi-temporal aerial images of Storglaciären, Sweden (1959-99). Part 1: Determination of length, area, and volume changes. Cryosphere, 4, 333-343 (doi: 10.5194/tc-4-333-2010)

Korona J, Berthier E, Bernard M, Rémy F and Thouvenot E (2009) SPIRIT SPOT 5 stereoscopic survey of polar ice: reference images and topographies during the fourth International Polar Year (2007-2009). ISPRS J. Photogramm. Rem. Sens., 64(2), 204-212 (doi: 10.1016/j.isprsjprs.2008.10.005)

Kuhn M, Markl G, Kaser G, Nickus U, Obleitner F and Schneider H (1985) Fluctuations of climate and mass balance: different responses of two adjacent glaciers. Z. Gletscherkd. Glazialgeol., 21, 409-416

Le Bris R, Paul F, Frey H and Bolch T (2011) A new satellite-derived glacier inventory for western Alaska. Ann. Glaciol., 52(59), 135-143 (doi: 10.3189/172756411799096303)

Marzeion B, Jarosch AH and Hofer M (2012) Past and future sealevel change from the surface mass balance of glaciers. Cryosphere, 6, 1295-1322 (doi: 10.5194/tc-6-1295-2012)

McNabb R and 9 others (2012) Using surface velocities to calculate ice thickness and bed topography: a case study at Columbia Glacier, Alaska, USA. J. Glaciol., 58(212), 1151-1164 (doi: 10.3189/2012JoG11J249)

Nuth C and Kääb A (2011) Co-registration and bias corrections of satellite elevation data sets for quantifying glacier thickness change. Cryosphere, 5, 271-290 (doi: 10.5194/tc-5-271-2011)

Paul F (2010) The influence of changes in glacier extent and surface elevation on modeled mass balance. Cryosphere, 4, 569-581 (doi: 10.5194/tc-4-569-2010)

Paul F and Haeberli W (2008) Spatial variability of glacier elevation changes in the Swiss Alps obtained from two digital elevation models. Geophys. Res. Lett., 35(21), L21502 (doi: 10.1029/ 2008GL034718)

Pfeffer WT, Harper JT and O'Neel S (2008) Kinematic constraints on glacier contributions to 21 st-century sea-level rise. Science, 321(5894), 1340-1343 (doi: 10.1126/science.1159099)

Pfeffer WT and 19 others (2014) The Randolph Glacier Inventory: a globally complete inventory of glaciers. J. Glaciol., 60(221), 537-552 (doi: 10.3189/2014JoG13J176)

Radić V and Hock R (2011) Regionally differentiated contribution of mountain glaciers and ice caps to future sea-level rise. Nature Geosci., 4(2), 91-94 (doi: 10.1038/ngeo1052)

Van Beusekom AE, O'Neel SR, March RS, Sass LC and Cox LH (2010) Re-analysis of Alaskan benchmark glacier mass-balance data using the index method. USCS Sci. Invest. Rep. 5247, 16

VanLooy J, Forster R and Ford A (2006) Accelerating thinning of Kenai Peninsula glaciers, Alaska. Geophys. Res. Lett., 33(21), L21307 (doi: 10.1029/2006GL028060.)

Zemp M, Hoelzle M and Haeberli W (2009) Six decades of glacier mass-balance observations: a review of the worldwide monitoring network. Ann. Glaciol., 50(50), 101-111 (doi: 10.3189/ $172756409787769591)$

Zemp M and 16 others (2013) Reanalysing glacier mass balance measurement series. Cryosphere, 7, 1227-1245 (doi: 10.5194/ tc-7-1227-2013) 